\title{
THE CHARACTERISTICS OF ADOLESCENTS NASOPHARYNGEAL CARCINOMA PATIENTS IN MOHAMMAD HOESIN GENERAL HOSPITAL PALEMBANG JANUARY 2013-DECEMBER 2017
}

\author{
Melania*, Denny Satria Utama \\ Department of Otorhinolaryngology Head and Neck Surgery Faculty of Medicine Universitas Sriwijaya/RSUP Dr. Mohammad Hoesin Palembang
}

\begin{abstract}
Introduction: Nasopharyngeal carcinoma is (NPC) mostly found in men of productive age with a ratio of men and women 2,18: 1 and 60\% of patients age between 25 and 60 years. NPCs are very rarely found in adolescents, namely age 11 to 21 years.

Objective: To determine the characteristics of nasopharyngeal carcinoma in adolescent patients at ORL-HNS Department of Dr. Mohammad Hoesin General Hospital Palembang.

Method: This is a descriptive retrospective study. The sample is all patients diagnosed with NPC in adolescence at ORL-HNS Department of Dr. Mohammad Hoesin General Hospital Palembang in January 2013 to December 2017 period.

Results: In this study, the number of adolescent NPC patients from January 2013 to December 2017 was 12 patients. The majority of adolescent NPC patients were male $(66,6 \%)$. The most common histopathological finding was WHO 2B (50\%). Based on the T category, largely, the patients were T4 $(41,6 \%)$. Most patients with Nodules were N3 $(58,3 \%)$ and came to the ENT clinic were already in stage IV $(41,6 \%)$

Conclusion: Adolescent nasopharyngeal carcinoma is more common in men than women (2: 1), and shows a response to proper therapy.
\end{abstract}

\section{Article Info}

Keywords:

Nasopharyngeal carcinoma, characteristics, adolescents

\section{*Corresponding author}

Address: Jl. Mayor Salim Batubara Lr. Belimbing 2 No. 5, RT/RW 32/10 Komplek Hamid King, Kelurahan Sekip Jaya, Kecamatan Kemuning, Kota Palembang, 30126, Indonesia

e-mail:docmelania@gmail.com

\section{INTRODUCTION}

Nasopharyngeal carcinoma (NPC) has multifactorial etiology and risk factors, which is a combination of interactions between environmental, genetic, and Epstein-Barr Virus infections (EBV). Significant biological exposure in nasopharyngeal carcinogenesis is Epstein-Barr Virus (EBV) infection which is characterized by an abnormal increase in viral capsid antibody-antigen of EBV and early EBV antigen. Various physical and chemical exposures that may lead to NPC are related to lifestyle, occupational, and environmental exposures include smoking, salted or preserved food and alcoholic beverages consumption, cigarette smoke, wood dust and so on. Evidence of the leading causes role such as various inhalant substances, herbal medicines and exposure in the workplace environment towards the incidence of NPC is still not consistent [1-5]. The world highest incidence of nasopharyngeal carcinoma is found in residents of the Southern China mainland, especially the Cantonese in Guangdong province and Guangxi region with numbers reaching more than 50 per 100.000 population each year. The incidence of nasopharyngeal carcinoma in Indonesia is quite high, which is around 4.7 new cases per 100,000 population every year or approximately $7000-8000$ cases per year throughout Indonesia. Between 2013 and 2016 there were 506 cases found in the ORL- HNS Department of Medical Faculty University of Indonesia-Cipto Mangunkusumo General Hospital. While in ORL-HNS Department of Dr. Mohammad Hoesin General Hospital Palembang in 2013-2017, 284 cases were found [6,7].

Nasopharyngeal carcinoma is mainly found in men of productive age with a comparison of male and female patients of 2,18: 1 and 60\% of patients aged between 25 and 60 years. NPCs are very rarely found in adolescents, namely ages 11 to 21 years. Another problem in the management of NPC is the emergence of cases that occur at a young age which is thought to be due to unhealthy lifestyles such as childhood exposure to cigarette smoke, consumption of ready-to-serve foods with many artificial flavorings, coloring and preservatives or other carcinogens. The study of the Age Standardized Rate (ASR) and Age
Standardized Cancer Ratio (ASCAR) of NPC at Dr. Kariadi Hospital Semarang in 2002-2011 showed a consistent year-to-year increase, accompanied by an increase in NPC cases at the age of under 20 years $[8-10,17]$.

\section{MATERIAL AND METHODS}

This is a retrospective descriptive study. Data were obtained from medical records of nasopharyngeal carcinoma patients in adolescence at ORL-HNS Department of Dr. Mohammad Hoesin General Hospital Palembang. The sample was collected by consecutive sampling with the criteria of all nasopharyngeal carcinoma- prone patients aged 11 to 21 years. This study describes the patient demographic data which includes the number and sex of the patient and also the histopathology, T size, nodule size, stage and distant metastases, and therapeutic response. This study was aimed to determine the characteristics of nasopharyngeal carcinoma in adolescent patients at ORL-HNS Department of Dr. Mohammad Hoesin General Hospital Palembang and expected that the results might give the baseline for the following study. The results are presented descriptively in the form of narratives and tables.

\section{RESULT}

Based on the medical records of ORL-HNS Department of Dr. Mohammad Hoesin General Hospital Palembang, the number of adolescent patients with nasopharyngeal carcinoma in January 2013 to December 2017 was 12 patients. In this report out of 12 patients, 8 were male $(66,7 \%)$ and $4(33,3 \%)$ were female. The distribution of nasopharyngeal carcinoma patients can be seen in Table 1 . 
Table 1. The Distribution of Nasopharyngeal Carcinoma Patients

\begin{tabular}{|c|c|c|}
\hline Data & n & $\%$ \\
\hline \multicolumn{3}{|l|}{ Sex } \\
\hline Male & 8 & 66.7 \\
\hline Female & 4 & 33.3 \\
\hline \multicolumn{3}{|l|}{ Age } \\
\hline 14 & 1 & 8.33 \\
\hline 15 & 1 & 8.33 \\
\hline 17 & 1 & 8.33 \\
\hline 18 & 2 & 16.6 \\
\hline 19 & 3 & 25 \\
\hline 20 & 4 & 33.3 \\
\hline \multicolumn{3}{|l|}{ Histopathological features } \\
\hline WHO 1 & 1 & 8.33 \\
\hline WHO $2 \mathrm{~A}$ & 3 & 25 \\
\hline WHO 2B & 6 & 50 \\
\hline WHO 3 & 2 & 16.6 \\
\hline \multicolumn{3}{|l|}{ Tumor } \\
\hline $\mathrm{T} 1$ & 1 & 8.33 \\
\hline $\mathrm{T} 2$ & 2 & 16.6 \\
\hline $\mathrm{T} 3$ & 4 & 33.3 \\
\hline $\mathrm{T} 4$ & 5 & 41.6 \\
\hline \multicolumn{3}{|l|}{ Nodules } \\
\hline No & 1 & 8.33 \\
\hline N1 & 3 & 25 \\
\hline $\mathrm{N} 2$ & 1 & 8.33 \\
\hline N3 & 7 & 58.3 \\
\hline \multicolumn{3}{|l|}{ Stage } \\
\hline I & 1 & 8.33 \\
\hline II & 2 & 16.6 \\
\hline III & 4 & 33.3 \\
\hline IV & 5 & 41.6 \\
\hline \multicolumn{3}{|l|}{ Condition } \\
\hline Deceased & 1 & 8.33 \\
\hline Complete response & 2 & 16.6 \\
\hline Responded to therapy & 7 & 58.3 \\
\hline Not responded & 1 & 8.33 \\
\hline Missed follow up & 1 & 8.33 \\
\hline Total & 12 & 100 \\
\hline
\end{tabular}

Adolescent patients with nasopharyngeal carcinoma who sought treatment were in the group of age ranged from 14 to 20 years. Age 20 dominated the adolescent NPC patients with as many as 4 patients $(33,3 \%)$, followed by age 19 (3 patients, $25 \%)$, age 18 ( 2 patients, $16,6 \%)$, age 17,15 , and 14 respectively 1 patient $(8,33 \%)$. The age distribution of adolescent nasopharyngeal carcinoma patients based on age can be seen in Table 1 .

Based on histopathological features, the highest number of adolescent nasopharyngeal carcinoma patients was WHO 2B nasopharyngeal carcinoma of 6 patients (50\%). Furthermore, the most histopathological view of nasopharyngeal carcinoma was WHO $2 \mathrm{~A}$ with 3 patients $(25 \%)$ followed by WHO 3 and WHO 1 (2 patients, 16,6\% and 1 patient, 8,33\%, respectively). Distribution of adolescent nasopharyngeal carcinoma patients based on histopathological features can be seen in Table 1 .

From the description of computed tomography for the location of the tumor, the highest number was T4 tumors with as many as 5 patients $(41,6 \%)$, followed the T3 tumors (4 patients, 33,3\%), T2 (2 patients, $16,6 \%)$, and the last was T1 with 1 patient $(8,33 \%)$. Distribution of tumor images based on computer tomography can be seen in Table 1 .

Based on the description of neck lymph node metastasis, obtained from this report the most common nodules were N3 nodules of 7 patients $(58,3 \%)$. Furthermore, most of the N1 nodules were 3 patients $(25 \%)$, N0 and $\mathrm{N} 2$ respectively 1 patient $(8,33 \%)$. The distribution of adolescent nasopharyngeal carcinoma patients based on neck lymph node nodules can be seen in Table 1 .

In this report, the majority of patients were stage IV nasopharyngeal carcinoma ( 5 patients, $41,6 \%)$. There were 4 patients $(33,3 \%)$ with stage III nasopharyngeal carcinoma; 2 patients $(16,6 \%)$ had stage II nasopharyngeal carcinoma and only 1 patient $(8,33 \%)$ showed stage I nasopharyngeal carcinoma. The distribution of adolescent nasopharyngeal carcinoma patients based on their stage can be seen in Table 1 .

Based on the response and the condition of the patient to therapy, nasopharyngeal carcinoma patients currently die as many as 1 patient $(8,33 \%)$. A number of 2 patients $(16,6 \%)$ responded completely and down to stage T0N0M0, as many as 7 patients $(58,3 \%)$ experienced progress intherapy, 1 patient $(8,33 \%)$ did not respond to therapy and 1 patient $(8,33 \%)$ did not show up for follow up. Distribution of adolescent nasopharyngeal carcinoma patients based on the response to therapy in Table 1 in Condition line.

\section{DISCUSSION}

Nasopharyngeal carcinoma is mainly found in men of productive age with a comparison of male and female patients of 2,18: 1 and $60 \%$ of patients aged between 25 and 60 years. NPCs are very rarely found in adolescents, namely ages 11 to 21 years. In the ORL-HNS Department of Dr. Mohammad Hoesin General Hospital Palembang in the period of 2013-2017 were found 284 cases. In this report, the number of adolescent nasopharyngeal carcinoma patients was 12 patients. Amelia et al. from the Department of Pediatrics of Cipto Mangunkusumo General Hospital from 2005 until 2009 found 24 people with NPC with an age range of 7-17 years old. The high percentage of NPC at such a young age is estimated to be related to genetic factors and also frequently exposed to carcinogenic substances from the environment $[11,12,16]$. In this report, it was found that nasopharyngeal carcinoma was more common in men than women in a ratio of 2:1.

According to a study conducted by Adham $\mathrm{M}$ et al., it was suggested that nasopharyngeal carcinoma was more prevalent among men than women with a ratio of 2-3:1. This explains a little bit that nasopharyngeal carcinoma is influenced by sex. This may be because several leading factors of nasopharyngeal carcinoma are often found in men, such as smoking, drinking alcohol, and exposure to wood dust $[13,14]$.

In this report, the most common histopathological features of nasopharyngeal carcinoma were WHO IIB types (6 patients). The research conducted by Yenita et al in West Sumatra found that histopathological findings of nasopharyngeal carcinoma largely were WHO IIB. The WHO IIB depiction has a better prognosis. In this report, the highest number of patient's computed tomography imaging was T4 (5 patients). Hidden nasopharyngeal sites and unusual symptoms often make patients have a consultation when the tumor is already in a larger state. From the picture of the neck lymph node nodules, it was found that the majority of patients with $\mathrm{N} 3$ lymph node enlargement with as many as 7 patients. Painless and slowly growing neck lymph nodes often make patients ignore complaints from the neck. Hence, patients came when they were already in an advanced stage $[6,8]$.

In this report, 5 patients arrived with stage IV, 4 patients with stage III, 2 patients came with stage II, and 1 patient with stadium. In a study conducted by $\mathrm{Li}$ et al, patients came in as much as $42.25 \%$. Factors of ignorance of patients, where the nasopharynx is hidden, symptoms that are not typical of nasopharyngeal carcinoma often make patients come already in an advanced stage. In addition, symptoms of lumps that are felt painless often make patients ignore the disease [7, 15].

\section{CONCLUSION}

Based on the results from the study and discussion, it can be concluded that the patients of nasopharyngeal carcinoma in adolescence with an age range of 11-21 years who came to the ORL-HNS Department of Dr. Mohammad Hoesin General Hospital Palembang during January 2013 To December 2017 were as many as 12 patients with a male to female ratio of $2: 1$; most cases occurred at the age of 20 years. The most seen histopathological features were WHO 2B (6 patients, 50\%). The tumor size was mostly T4 (5 patients, $41,6 \%)$. The size of the most nodules was N3 in 7 patients $(58,3 \%)$. Most patients presen Based on the results from the study and discussion, it can be concluded that the patients of nasopharyngeal carcinoma in adolescence with an age range of 11-21 years who came to the ORL-HNS Department of Dr. Mohammad Hoesin General Hospital Palembang during January 2013 To December 2017 were as many as 12 patients with a male to female ratio of $2: 1$; most cases occurred at the age of 20 years. The most seen histopathological features were WHO 2B (6 patients, 50\%). The tumor size was mostly T4 (5 patients, $41,6 \%$ ). The size of the most nodules was N3 in 7 patients $(58,3 \%)$. Most patients presented in stage IV (5 patients, 41,6\%). Adolescent nasopharyngeal carcinoma patients showed a response to good therapy as many as 7 patients $(58,3 \%)$ in stage IV (5 patients, $41,6 \%)$. Adolescent nasopharyngeal carcinoma patients showed a response to good therapy as many as 7 patients $(58,3 \%)$. 


\section{REFERENCE}

[1] Soetirto I, Hendarmin H, Bashiruddin J. Buku Ajar Ilmu Kesehatan Telinga Hidung Tenggorok Kepala dan Leher. Edisi Keenam. Soepardi EA, Iskandar N, Bashiruddin J, Restuti RD, editor. Gangguan Pendengaran dan Kelainan Telinga Jakarta: Balai Penerbit FKUI. 2007;10.

[2] Wei W, Chua D. Nasopharyngal cancer. Dalam Bailey BJ, Healey GB, Johnson JT, Rosen CA dkk, penyunting. Head and neck surgeryotolaryngology Philadelphia Lippincott Williams \& Wilkins Edisi ke-4. 1875;97.

[3] Fachiroh J, Schouten T, Hariwiyanto B, Paramita DK, Harijadi A, Haryana SM, et al. Molecular diversity of Epstein-Barr virus IgG and IgAAntibody Responses in Nasopharyngeal Carcinoma: A Comparison of Indonesian, Chinese, And European Subjects. The Joumal of Infectious Diseases. 2004:53-62.

[4] Sriamporn S, Vatanasapt V, Pisani P, Yongchaiyudha S, Rungpitarangsri V. Environmental Risk Factors for Nasopharyngeal Carcinoma: A CaseControl Study in Northeastern Thailand. Cancer Epidemiology and Prevention Biomarkers. 1992;1(5):345-8.

[5] Asri A. Korelasi antara Latent Membrane Protein-1 Virus Epstein-Barr dengan P53 pada Karsinoma Nasofaring (Penelitian Lanjutan). Jurnal Kesehatan Andalas. 2012;1(1).

[6] Chan A, Grégoire V,Lefebvre J-L, Licitra L, Felip E, Group EEEgw. Nasopharyngeal Cancer: EHNS-ESMO-ESTRO Clinical Practice Guidelines for Diagnosis, Treatment and Follow-Up. Annals of Oncology. 2010;21(suppl 5):v187-v9.

[7] Chang ET, Adami H-O. The Enigmatic Epidemiology of Nasopharyngeal Carcinoma Cancer Epidemiology and Prevention Biomarkers. 2006;15(10):1765-77.

[8] Ballenger JJ. Tumor dan Kista di Muka, Faring dan Nasofaring dalam Penyakit Telinga, Hidung, Tenggorok Kepala dan Leher, Jilid 1, Alih Bahasa Staf Ahli Bagian THT RSCM FK-UI, Indonesia. Binarupa Aksara Publisher, p 359-396.

[9] Sim EU-H, Toh AK-L, Tiong T-S. Preliminary Findings of DownRegulated Genes in Nasopharyngeal Carcinoma. Asia Pacific Journal of Molecular Biology and Biotechnology. 2008;16(3):79-84.

[10] Ariwibowo H. Faktor Risiko Karsinoma Nasofaring. Cermin Dunia Kedokteran. 2013;40(5):348-51.

[11] Muna NI. Hubungan Paparan Debu Kayu dan Formaldehid dengan Faktor Risiko Terjadinya Karsinoma Nasofaring (Studi Observasional pada Pasien Keganasan Kepala Leher di Klinik Telinga Hidung Tenggorok-Bedah Kepala dan Leher RS. Dr. Kariadi Periode 1 April 2008-15 Juni 2008). Universitas Diponegoro. 2008;1-26.

[12] Cempako G, Windiastuti E. Karsinoma Nasofaring pada Anak: Karakteristik, Tata Laksana dan Prognosis. Sari Pediatri. 2016;13(1):79-84.

[13] Bray F, Haugen M, Moger TA, Tretli S, Aalen OO, Grotmol T. Age-Incidence Curves of Nasopharyngeal Carcinoma Worldwide: Bimodality in Low-Risk Populations and Aetiologic Implications. Cancer Epidemiology and Prevention Biomarkers. 2008;17(9):2356-65.

[14] Lu JJ, Grégoire V, Lin S. Selection and Delineation of Target Volumes in Intensity-Modulated Radiation Therapy for Nasopharyngeal Cancer. Nasopharyngeal Cancer: Springer; 2010. p. 213-32.

[15] Marlinda A, Andriastuti M, Irwan, Lisnawati, Ukhrowiyah Y. Diagnosis dan Penatalaksanaan Karsinoma Nasofaring pada Anak. Case report. Universitas Indonesia. 2010;1-14

[16] Tirtosastro S, Murdiyati A. Kandungan Kimia Tembakau dan Rokok. Buletin Tanaman Tembakau, Serat \& Minyak Industri. 2017;2(1):33-44.

[17] Firdaus MA, Prijadi J. Kemoterapi Neoadjuvan pada Karsinoma Nasofaring. Universitas Andalas. 2009;1-11 